Page 27-38. ISBN: 978-602-6 988-75-1

Web Jurnal Online: jurnal.unmuhjember.ac.id

By: Emy Kholifah R.; Ahmad Mustanir

Food Policy And Its Impact On Local Food

\title{
FOOD POLICY AND ITS IMPACT ON LOCAL FOOD
}

\author{
EmyKholifah R. (emykholifah25@ gmail.com) \\ (Universitas MuhammadiyahJember, JawaTimur) \\ Ahmad Mustanir (ahmadmustanir74@gmail.com) \\ (UniversitasMuhammadiyah Sidenreng Rappang, Sulawesi Selatan)
}

\begin{abstract}
This study analyzes food policy in relation to the existence of local food. This policy, among others, regulates availability, affordability, food institutions and community participation. Solving food availability is done by creating food reserves (central government level, regional government and community). Food reserves can be obtained from domestic production and food imports. Domestic food availability is carried out intensively through diversification of food proclaimed by the government through diversification of food based on local resources. This effort is expected to have a significant impact on the existence of local food, but its implementation up to seven years ago, the existence of local food still cannot occupy the expected position. The deterioration experienced due to past policies that led to the emergence of rice as the main food supremacy of the community, has not yet been restored. And, moreover, the position of imported food, which is increasingly not easily dammed. This study strengthens the analysis above by discussing the existence of local food for example corn, sago or sweet potatoes.
\end{abstract}

Keywords: food policy, local food, food imports 


\section{INTRODUCTION}

Policy analysis is one of the disciplines in applied Social Sciences to produce relevant information about policy, so that it can be utilized in order to solve policy problems. Policy analysis is expected to be able to produce information and arguments about: Values which are benchmarks for problems to be overcome, facts that can be considered as limiting or increasing value, actions that can produce value. For that purpose there are three approaches in policy analysis: an empirical / analytical approach is an approach that explains the causal relationship of a policy; evaluative approach that is assessing the value of a policy, and a normative approach is an approach that provides recommendations for future policy formulation. (William N. Dunn, 2003)

Meanwhile there are two types of public policy analysis, namely prospective policy analysis and restropective policy analysis. Prospective policy analysis is a policy analysis carried out before policy action is initiated and implemented. Prospective policy analysis is a tool for preparing information to be used in formulating alternative and policy preferences that are expressed comparatively, predicted in quantitative and qualitative languages as a basis or guide in policy decision making. Whereas, Retrospective Policy Analysis is a policy analysis carried out after the policy is taken. This analysis is application-oriented analysis. This policy analysis studies the implementation of policies and the extent of policy outcomes and benefits. In this policy analysis, it is also concerned with achieving goals and objectives of policy makers and stakeholders. The results of policy analysis will contain information on policy goals and objectives that provide a basis for monitoring and evaluating specific policy outcomes, which can be used by practitioners to formulate policy issues, develop alternative alternatives to new policies, and recommend direction of actions to solve the problem. Integrated Policy Analysis is an analysis that combines attention to the creation and transformation of information before and after policy actions are taken.

This study seeks to analyze food policy in Indonesia, using a retrospective approach. Reptrospective in Law number 18 of 2012 which attempts to analyze how this policy impacts on the existence of local food. Other laws that have been issued before the law are number 7/1996 and Presidential Regulation 22/2009 will also be part of this policy analysis in order to complete the information needed. This policy, because it has been promulgated since 2012, the data that will be displayed to show the impact of the policy is the data resulting from the application of policies, especially those relating to the objectives, objectives and benefits of the policy.

This research is descriptive qualitative research (LexyMoleong, 2007, Milles, Mattew B., Huberman, A. Michael, 2007). The focus of research on national food security policies is related to the existence of local food commodities, namely corn, sago food and cassava / cassava food. The data sources used in this study are secondary data sources (documents) both hard copy and soft copy data through online searching. Online data can be in the form of newspaper publications, statements on blogs or from online books / e-books. 


\section{RESULT}

The issue that is currently developing about local food is that food production and people's interest in consuming local food are very low. If this continues, then the deterioration of local food cannot be avoided. Local food, which was once prosperous, can be found, between lan, on corn, sago food and sweet potato food. The Indonesian nation, which consists of many tribes, has a variety of staple foods, in fact, hundreds of types of food. Each becomes a unique part of this nation's oneness. Biodiversity-based food diversity is geographically owned by the Indonesian people. Food diversity is a local wisdom that is greatly admired by other nations. consciously or unconsciously, in the 1970s, the government actually began to echo the policy of rice food as staple food. This food is stated to be better and has more nutritional value than other staple foods. The legality of rice being the main food is obtained through the policy of Agrarian Reform, this agricultural policy directly or indirectly, encouraging food consumption of local people turning to rice.

Since then, local food margins (sago, sweet potatoes, corn) have begun through the use of the term traditional food. Meanwhile, rice food, increasingly famous for the term 'sego putih' (white rice) is inversely proportional to its image with 'sego-corn', 'dried cassava', 'gatot', sago, or 'empok-maize' (corn mill residue powder which is usually for duck animal feed). Image that inequality continues to this day, as the generation changes, as if it has become commonplace. Food for rice is the consumption of staple foods that cannot be de-verified with other food, more food that is considered traditional. Supremacy of 'sego putih' food up to now and local food has shifted into hawker food (additional food).

That is ironic when the food law number 12/2012 explicitly mandates the development of food security based on local food availability. And even, Presidential Regulation number 22/2009 actually specializes in being a law in local food development because the regulation immediately diverts to accelerating the diversification of local resource-based food consumption. Why this can happen, whether this law has not been able to achieve the policy target, because the government adheres to a food policy that is very accommodating to international trade policies, such as the Asean Free Trade Area, so that food imports are open and even guaranteed by law . Or, the current food policy has not been able to reach the policy target because the government does not implement the policy well, or also, the local community itself is unable to arouse the spirit of producing local food commodities, even though it has been explicitly facilitated, in some food laws ( Presidential Regulation number 22 of 2009 and Law number 18/2012).

Basically, the 2012 policy explicitly made improvements from upstream to downstream in seeking food independence, food security and food availability. Food independence which is the ability of the state and nation to produce diverse foods from within the country that can guarantee the fulfillment of sufficient food needs at the individual level by utilizing the potential of natural, human, social, economic and local wisdom in a dignified manner. Food independence is closely related to how much food security is. Food security is a condition of fulfilling food for the state up to individuals, which is reflected in the availability of adequate food, both in quantity and quality, safe, diverse, nutritious, equitable and affordable and does not conflict with the religion, beliefs 
and culture of the community, to can live a healthy, active and productive life in a sustainable manner. Two important diction in food policy in 2012, shows the importance of food production and food availability. Food availability in the food law is a condition of the availability of food from domestic production and national food reserves and imports if the two main sources cannot meet the needs. (Article 1 of the Food Law number 18/2012).

\section{a. $\quad$ Food Security Policy in Supporting the Existence of Local Food}

Law No. 7/1996 provides an understanding of food security as a condition for fulfilling food for households as reflected in: (1) adequate availability of food, both in quantity and quality; (2) safe; (3) evenly distributed; and (4) affordable, not much different from the definition of food security formulated in Law number 18/2012 which emphasizes that food security is the fulfillment of food for the country to individuals. While the policies and programs that will be taken to realize food security are divided into three programs which are grouped into three program stages. Long, medium and short term programs. Short term programs (up to 5 years), namely Programs aimed at increasing national food production capacity by using existing resources and proven technology. The main components of this program are: extensification or expansion of agricultural land (140,000 hectares / year). Extensification of agricultural land is intended to expand agricultural production land, so that national food production can now be increased. Extensification was carried out mainly for soybeans, sugar and salt because of the ratio of imports to large production (30-70\%). The expanded land is for poor farmers and farmers $(<0.1$ hectares), but has farming expertise / experience. Potential dry land of 31 million hectares can be used as farming land.

In addition to the extensification program, an intensification program for agriculture was also carried out. This program is a program aimed at increasing production through increasing agricultural productivity. Intensification is aimed at fertile and productive agricultural lands which are already food storage areas such as Kerawang, Subang and other northern coastal areas, in West Java, East Java, Central Java, and other provinces. Complementing the agricultural extension and intensification program, a diversification program for agricultural production was also carried out. This program is aimed at increasing alternative staple food production besides rice, decreasing rice consumption and increasing balanced and nutritious alternative staple food consumption and based on local food. Diversification is done by accelerating the implementation of post-harvest technology and processing of local food that has been researched into the industry.Another program is the Revitalization of the Post-Harvest Industry, and Food Processing. This program is the revitalization / restructuring of the post-harvest and food processing industries which leads to, emphasizing the quality and processing of crop yields from raw materials to semi-finished materials or finished materials that have added value. The next program is, Revitalization and Restructuring of Food Institutions. The existence, role and function of food institutions such as farmer groups, SMEs, cooperatives need to be revitalized and restructured to support the development of food independence.

Meanwhile, the medium-term program is aimed at strengthening the development of more efficient and effective food security and high competitiveness, through 
improving agricultural land laws including the regulation of farmland area owned by farmers, ownership of agricultural land by non-farmers. The bawon system or the profit sharing of owners and cultivators, etc. The modernization of agriculture is carried out with the aim of getting closer to increasing the efficiency and productivity of agricultural land as well as a medium-term program. Also included is the development of road infrastructure and facilities for agricultural areas, so that agricultural activities are more dynamic.Food policy number 7 of 1996 was strengthened by an accelerated effort towards the goal of diversifying local resource-based food consumption (Presidential Regulation number 22 of 2009). This shows that the government has more attention to the success of local food development which is expected to support national food security. This policy encourages increased participation of Local Governments for the development and implementation of local resource-based diversification of food consumption programs. This policy uses strategies through internalizing diversification of food consumption (carried out through advocacy, campaigns, and promotions), and conducting education (both formal and non-formal). On the other hand this acceleration strategy is carried out through the development of local food businesses and industries. This policy was designed in two stages, the internalization stage and the second phase of business development and the local food industry which was completed until 2015.

Strengthening food security seems to be enough to grab the government's attention. Thus, the government feels the need to reformulate the rules in 2012. Especially in an effort to reaffirm the role of local governments to realize food security (where this is emphasized in Presidential Regulation 22/2009). In accordance with the principle of decentralized government, local governments have obligations and also the right to carry out development in their respective regions. Local governments have an obligation to improve and develop food security through their own food security.

Food security, which is one of the principles of food management in Law number 18 of 2012, aims to several things, including increasing the ability to produce food independently; provide diverse food and fulfill the requirements of security, quality and nutrition for public consumption; realize the level of food sufficiency, especially staple food at reasonable and affordable prices in accordance with community needs. In addition, the aim is to facilitate or increase access to food for the community, especially for people who are prone to food and nutrition; increasing the added value and competitiveness of Food commodities in the domestic and foreign markets; increase public knowledge and awareness about safe, quality and nutritious food for public consumption; improve welfare for farmers, fishermen, fish farmers, and food business actors; and protect and develop a wealth of national food resources.

Food security can be achieved through the implementation of holistic arrangements starting from food planning, regulation of food availability; food affordability; food and nutrition consumption; food security; Food labels and advertisements; supervision; Food information system; Food research and development; Food institutions; community participation; and investigation. In terms of food planning, it is stipulated in long-term development plans, medium-term development plans, and annual work plans at the national, provincial and district / city levels in accordance with the provisions of the legislation. Planning that has been made by the government, and 
local governments (both provinces and districts / cities) must involve the role of the community. Likewise with regulating the availability of food, the government and regional governments determine the types of local food that can be favored by involving the role of local communities. This means that the government must develop as much as possible local food to achieve sufficient availability of wish (article 12 of the Food Law number 18/2012).Furthermore, arrangements for realizing food availability through domestic (local) food production are carried out by: developing food production that relies on local resources, institutions and culture; developing the efficiency of the Food business system; developing facilities, infrastructure, and technology for the production, postharvest handling, processing and storage of food; build, rehabilitate and develop infrastructure for food production; maintain and develop productive land; building a food production center; the government establishes local food production centers according to the proposals of regional governments.

For food availability based on local resources, the government still provides the possibility to fulfill food availability by regulating the existence of food reserves originating from domestic production, and from abroad (food imports) according to needs (Article 14 of the Food Law number 18 / 2012). However, the government cannot ignore the onslaught of external food items in which the government has participated in ratifying international free trade policies (AFTA and others). Article 36 of this Law states that food imports are only carried out if national food reserves are insufficient. The national food security policy, one of which is aimed at increasing domestic food production facilitated in Law Number 12/2012, is mainly related to the improvement of human resources, natural resources, funding sources, science and technology, food infrastructure and food institutions. All the policy support (article 18) is intended so that the government and regional governments can develop the domestic food potential.

\section{b. Food Diversification Policy Does Not Restore Local Food Supremacy}

Food diversification is a program that encourages people to vary the staple food consumed, so as not to focus on just one type of staple food. Kasryno, et al (1993) views food diversification as an effort that is very closely related to improving the quality of human resources, agricultural development in the food sector and improving community nutrition. This food diversification includes aspects of production, consumption, marketing and distribution.

Based on the aspect of production, diversification means the broadening of the spectrum of food commodities both in terms of expanding resource use, commodity exploitation and the development of food commodity production. This indicates that diversification includes the notion of horizontal and vertical diversification. Food consumption, food diversification includes behavioral aspects based both on economic considerations such as commodity income and prices, as well as non-economics such as habits, tastes and knowledge. The meeting between the production and consumption sectors is inseparable from the role of marketing and distribution of these food commodities. Meanwhile, Soetrisno (1998) defines food diversification more narrowly (in the context of food consumption), namely as an effort to diversify the types of food consumed, including food sources of energy and nutrients. This is intended to be able to 
meet the needs for food and nutrition in accordance with adequacy both in terms of quantity and quality.

According to Suhardjo and Martianto (1992), the more diverse the consumption of food, the better the quality of food consumed. Therefore the dimensions of food diversification are not only limited to the diversification of consumption of staple foods, but also complementary foods. In Indonesia, food diversification is intended to vary the consumption of the Indonesian people so as not to focus on rice. Indonesia has a variety of agricultural products which can actually be used as staple foods such as breadfruit, sweet potatoes, taro, corn, potatoes and so on which can be the main supporting factors for food diversification.Food diversification in the Indonesian government is one way to achieve rice self-sufficiency by minimizing rice consumption so that total consumption does not exceed production. Basically food diversification includes three spheres of interrelated understanding, namely diversification of food consumption, diversification of food availability, and diversification of food production. Presidential Decree No. 68 concerning Food Security article 9 states that food diversification is held to improve food security by taking into account local resources, institutions and culture (Hanafie 2010). Whereas in Law number 18 of 2012, Food Diversification is an effort to increase the availability of diverse foods and based on the potential of local resources in order to: meet food consumption patterns that are diverse, nutritious, balanced and safe; developing food businesses; and / or, improve community welfare. Diversifying local food is basically an effort to optimize local food; technology development and incentive systems for local food processing businesses; introduction of new types of food, including untapped local food; development of diversification of farming and fisheries. On the other hand the aim is to increase the availability and access of seeds, seeds of plants, livestock and fish; optimizing land use, including yard area; strengthening of micro, small and medium enterprises in the food sector; and the development of a food industry based on local food.This is especially related to efforts to reduce rice consumption compensated by the addition of non-rice food consumption accompanied by supplementary food supplementation. Diversification of food consumption can also be defined as the number of types of food consumed, so that the more types of food consumed will be more diverse. The dimensions of diversification in food consumption are not only limited to basic food but also other types of food, because the diversification context is to improve the quality of people's nutrition in quality and quantity, as an effort to improve the quality of human resources.

The dependence on food consumption on rice is not beneficial for food security, especially those related to aspects of food sufficiency stability. The positive impact of the policy of diversifying food consumption includes strengthening food security. This is related to the issue of food security which is an important issue, therefore efforts to reduce the role of rice, and replace it with other types of food are important to do in order to maintain food security in the long term. This effort can be done by developing and introducing alternative food substitutes for rice that are cheap and have nutritional content that is not much different from rice.

Another impact of food diversification is increasing farmers' income and food agroindustry. Farmers will produce commodities that are needed by consumers and that 
have high prices. They will no longer depend on rice commodities as a source of income for their farming business, but can try other crops that have higher economic value. On the other hand, food diversification can also save the country's foreign exchange, the success of consumption diversification not only strengthens people's food security but also benefits the country's foreign exchange savings which means alleviating the country's financial burden especially when this economic crisis occurs. Unfortunately, food diversification policies are not intended to replace rice, but change the consumption patterns of people so that people will consume more types of food.

Rice is the most basic food commodity for most Indonesian people. In fact, rice is a food habit so people assume that it has not been said to eat if they have not eaten rice. Based on statistical data, the national consumption of rice reaches $139.5 \mathrm{~kg} /$ capita / year. This shows that Indonesian society is so dependent on rice. To meet the needs of rice, Indonesia still imports. Long-term rice imports can threaten national security. Alternative food was then made in an effort to reduce the dependence on Indonesian rice consumption. However, so far, the food diversification program has not been able to succeed fully because of the very strong community attachment to rice consumption.

\section{c. Food Import Policy and Local Food Availability}

Indonesia is one of the agricultural countries, where most of its inhabitants work in agriculture. Many people actually choose to become farmers rather than working as laborers, factories or in other industries. Most Indonesian farmers produce various kinds of export commodity crops, such as rice, fruits, vegetables, and so on. Although Indonesia is an agrarian country, it does not make the Indonesian state apart from imports. Especially rice, recorded since 1980 which in that year, Indonesia experienced food self-sufficiency and the government decided to import rice from outside. The government made a policy related to importation, especially in importing rice, because rice is the food that contributes to the largest food security in Indonesia. The development of the volume and value of rice export imports in Indonesia, during 1983-2016 the pattern of the development of rice import exports in Indonesia was quite high. And, the import volume is higher than its exports. Imports of rice in Indonesia reached 912.81 tons, an increase of $492.31 \%$ per year.

Indonesia, in 2015 imported 861.63 thousand tons of rice, mainly from Vietnam at 509.37 thousand tons (59.12\%). Then, from Pakistan 180.1 thousand tons (20.90\%) with a trade value of 62.95 million U \$ $\$$. Indonesia also imports rice from Thailand, India and Myanmar (Suwandi, Nuryati, Waryanto, \& A, 2016). This high import condition, it can be said, Indonesia's food security experienced a decline, because the government took more or imported rice from other countries. With the massive imports of food prices declined. And, it causes losses and the economic growth of the community is hampered. In fact, the government should pay more attention to the farmers' harvests, so that they do not turn off the enthusiasm of the community to continue farming and take advantage of the condition of the land they own. Moreover, local food, initiated through the diversification of local resource-based food, cannot replace community dependence on rice. Efforts to boost the level of consumption of corn, sweet potatoes and sago, for example, to replace rice food, when rice is in an expensive and rare position, have not been successfully carried out. This can be seen from the productivity 
of corn, cassava, and sago which remain unchanged both in productivity and market demand.Meanwhile, regulations that become the government's reference in importing food include, law number 10/1994 concerning customs, law number 8/1999 concerning consumer protection, Law number 17/2006 concerning food, law number 36 in 2009 concerning health, Presidential Decree No. 260 of 1997 concerning the affirmation of the duties and responsibilities of the minister of trade in the field of foreign trade. (Sihabudin, 2015), Law No. 18/2012 concerning food. Through these policies, importing food from the outside becomes very easy, so that Indonesia is increasingly dependent on imported food. The government also stipulates international trade policies, through the import policy the government can influence the structure, composition, and smooth running of businesses to protect and encourage the domestic economy and save foreign exchange. However, even though not always imported food from outside is approved by the community, especially the people who own agricultural land. People feel disadvantaged because imports of food, especially rice, make their income, from farming, decline.

The high number of rice imports, has made food security in Indonesia decline. Even though, Indonesia has great potential in agriculture such as mustard palm, rubber, cocoa, which is beginning to dominate the world market, but in food production of staple rice, more imports, especially from Vietnam, Pakistan, Thailand and India. This condition is caused by several things, including because of the large population, so that domestic food production is insufficient, so the government must import food. Another reason is that the dependence on rice is the main staple food of the community, so that the need for rice for each household is increasing. This need cannot be replaced by other staple foods such as corn, cassava / cassava and sago.

\section{CONCLUSION: FOOD POLICY, LOCAL FOOD DOWNTURN}

Food security policies carried out with the effort to achieve diversification (diversification) of food in fact experience an inability to eliminate people's dependence on food for rice. And, it is not able to erase the views of the people, who have already, put palawija as second class community food. And, on the other hand, there is an inability to revive the potential of food owned by each region, causing traditional food (from the regions) to be unpopular for consumption as staple food. This means that local food that has been painstakingly raised again (after long being eroded by food policy on agrarian reform that favored rice food), through efforts to diversify food policies, was unable to reposition itself as a staple food for the community. Traditional food / local food is only able to make itself as food anan snacks 'or second food (not staple food). This shift can be said as the deterioration of local food. On the other hand, food diversification policy does not explicitly make local food a substitute for rice surpemation, but 'only' as a diversification of food types (supplementary food for community nutrition).

Likewise, local cassava food, which is a tropical and subtropical annual plant, is widely known as one of the staple carbohydrate-producing foods which is a staple food typical of Indonesian society. Cassava generally grows and adapts widely in Indonesia. This plant grows and can be produced in lowland and highland areas. In the present, cassava is no longer a staple food, but is used as an industrial raw material, tapioca flour, 
cassava flour, as well as ethanol, gasohol, and others. Same with corn. Corn is grown to meet basic food needs. Later, corn is processed into starch, corn flour, snacks, pop corns, corn jelly, corn syrup and so on. After being unpopular as the main staple food, corn developed into non-food ingredients, for example it is used as animal feed ingredients, compost, paper and fuel wood. In Indonesia, some of the main corn producing centers are East Nusa Tenggara, North Sulawesi, East Java (Madura Island), Central Java, West Java, D.I. Yogyakarta, and so on. The spread of corn plants can grow and produce evenly anywhere, due to the characteristics of corn plants which are plants that can grow in subtropical and tropical regions.

Another local food that is known for its existence in the past as the main food ingredient is sago. This food is one of the popular food sources for some people of Indonesia, especially in eastern Indonesia and parts of Sumatra. The potential of sago as a national food alternative product is very likely and promising. This is due to the fact that the world sago producing area is currently held by Indonesia. not less than $60 \%$ of the total world sago area. In addition to potentially being one of the promising carbohydrate sources, sago plants can also be used as an ingredient in making adhesives, syrups and ethanol raw materials. Sago can also be used to make sago flour, which has a high nutrient content that is not inferior to tapioca flour and arrowroot aci.

Sago is a feature of food in several regions in Indonesia, especially in Papua. Papua is unique, not only in terms of culture, but also in people's consumption patterns. Besides sago, sweet potato is also a food that supports the food sufficiency of the people of Papua. Sweet potato is a staple food for most of the population in the interior, especially in the BaliemJayawijaya valley region. In addition to sweet potatoes, there are very few ecologically good crops that can be produced there, even using simple secular technology (Dimyati et al: 1991 in Rauf, 2009). As with sweet potatoes, sago is also a local plant that is a food source for Papuan people, especially in coastal areas. Sago trees in Papua grow naturally without acts of cultivation from the local population (Rauf, 2009). Sago is very suitable in swamp areas, where most of Papua's land is swamps. So, sago is an abundant source of food for the community.

Along with the food policy adopted by the government, about the green revolution, which drives mass rice production, this causes the price of rice to be cheap. This condition makes the position of sago and sweet potato as the staple food of the community, especially in Papua, starting to be displaced by rice (Budi: 2003 in Rauf, 2009). This can be seen from the amount of production and the planting of sweet potato and sago which continues to decline. Although, rice production and land area continue to increase, Papua is one of the regions experiencing food insecurity. This is because the ratio between the level of production and consumption is not balanced. Rice from the beginning was not a local food of Papua. Apart from its geographical area which is indeed not suitable, rice is also not a crop produced by local wisdom. Thus, efforts to force rice into staple foods and leave sago and sweet potatoes from the community have resulted in a situation of food insecurity. 
Proceeding ICOGISS 2019

Page 27-38. ISBN: 978-602-6 988-75-1

Web Jurnal Online: jurnal.unmuhjember.ac.id

By: Emy Kholifah R.; Ahmad Mustanir

Food Policy And Its Impact On Local Food

\section{REFERENCE}

Arifin, Bustanil, 1994, PanganOrdeBaru, KOPINFO. Jakarta

Bungin, Burhan. 2001, MetodologiPenelitianKualitatif,

AktualisasiMetodologisKeArahRagam Varian Kontemporer. Raja

GrafindoPersada

Basis Data Pertanian. 2001. http://aplikasi.deptan.go.id/bdsp/index.asp .Diakses 23 Juli 2011

BPS. 2011. Data Ekspor-Impor. http://www.bps.go.id/. Diakses 30 Juli 2011

BPS. 2012. Data Strategis BPS 2012. BadanPusatStatistik Investor Daily. 2012. Kuliner

Beri PendapatanTerbesarBagiIndustriKreatif. Diakses

dari http://www.investor.co.id/tradeandservices/kuliner-beri-pendapatan-

terbesar- $\quad$ bagi-industri-kreatif/49205KelompokKerja Indonesia Design Power-

Departemen Perdagangan. 2008. RencanaKerjaPengembanganEkonomiKreatif 2025. DepartemenPerdagangan RI Perkembangan Usaha Restoran/Rumah Makan

Berskala Menengah dan Besar Tahun 2007-2010, diakses

dari http://www.budpar.go.id/userfiles/file/rekaprestoran2007-2010.pdf

BadanKetahananPangan. 2009. PetaKetahanandanKerentananPangan Indonesia.

Diakses darihttp://bkp.deptan.go.id/file/petapangan/FSVA_Report.pdf

GambaranUmum

Papuaiakses http://www.dprp.go.id/index.php?option=com_content\&do_pdf=1

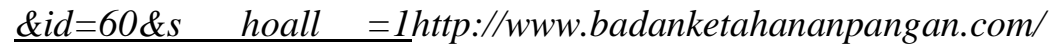

BPS. 2012. Data Strategis BPS 2012. BadanPusatStatistik Investor Daily. 2012. Kuliner

Beri PendapatanTerbesarBagiIndustriKreatif. Diakses

dari http://www.investor.co.id/tradeandservices/kuliner-beri-pendapatan-

terbesar- $\quad$ bagi-industri-kreatif/49205KelompokKerja Indonesia Design Power-

Departemen Perdagangan. 2008. RencanaKerjaPengembanganEkonomiKreatif 2025. DepartemenPerdagangan RI Perkembangan Usaha Restoran/Rumah Makan

Berskala Menengah dan Besar Tahun 2007-2010, diakses

dari http://www.budpar.go.id/userfiles/file/rekaprestoran2007-2010.pdf

BadanKetahananPangan. 2009. PetaKetahanandanKerentananPangan Indonesia.

Diakses darihttp://bkp.deptan.go.id/file/petapangan/FSVA_Report.pdf

GambaranUmum Papua,

diakses $\underline{\text { http://www.dprp.go.id/index.php?option }=\text { com_content } \& d o \_p d f=1 \& i d=6}$ O\&s hoall =1 http://www.badanketahananpangan.com/

Cahyantodkk. 2012. PenguatankearifanLokalsebagaiSolusiPermasalahanKetahanan

PanganNasional. Prosiding the 4th International Conference on Indonesian

Studies: $\quad$ Unity, Diveristy, dan Future

Dwijowinoto, NugrohoRiant. 2006. KebijakanPublikUntuk Negara-Negara Berkembang, Model-Model Perumusan, Implementasi, danEvaluasi.Gramedia Jakarta

Dunn, William N. 2003. PengantarAnalisiskebijakanPublik, edisiKedua. UGM Press

Miles, B. MatthiewdanHubbermanA.Michael. Analisis Data Kualitatif. 2007. UI Press Jakarta

Moleong, Lexy J., 2007. MetodologiPenelitianKualitatif. RK Surabaya

Parsons, Wayne. 2001, Public Policy, PengantarTeorydanPraktekKebijakan.Fajar Inter Pratama offset

Warr, Peter. 2005. Food policy and poverty in Indonesia: a general equilibrium

,DOI: $10.1111 / \mathrm{j} .1467-8489.2005 .00312$

UURI Nomor 18/2012 tentangPangan

UURI Nomor 7/1996 tentangPangan 
Proceeding ICOGISS 2019

Page 27-38. ISBN: 978-602-6 988-75-1

Web Jurnal Online: jurnal.unmuhjember.ac.id

By: Emy Kholifah R.; Ahmad Mustanir

Food Policy And Its Impact On Local Food

PeraturanPresidennomor 22 tahun 2009

tentangzKebijakanPercepatanPenganekaragamanKonsumsiPanganBerbasisSumb erdayaLokal

http://www.kompasiana.com/abiyadun/inilah-kebijakan-mewujudkan-swasembadapangan_56df136b569373071a11f96e

http://indaharitonang-fakultaspertanianunpad.blogspot.co.id/2013/06/kebijakanperdagangan-internasional.html

http://www.kompasiana.com/abiyadun/inilah-kebijakan-mewujudkan-swasembadapangan_56df136b569373071a11f96e

http://indaharitonang-fakultaspertanianunpad.blogspot.co.id/2013/06/kebijakanperdagangan-internasional.html

http://digilib.uinsby.ac.id/14890/6/Bab\%203.pdf, ProteksiDalamPerdagangan Di Indonesia

http://www.kemendagri.go.id/media/documents/2013/09/20/u/u/uu_no.19-2013.pdf , Undang-UndangRepublik Indonesia Nomor 19 Tahun 2013 TentangPerlindungan Dan PemberdayaanPetani

https://ekonomi.kompas.com/read/2017/01/19/163000126/serikat.petani.indonesia.kebija kan.pangan.masih.sebatas.produksi

https://www.matamatapolitik.com/opini-indonesia-butuh-kebijakan-pangan-yang-lebihbaik/

https://www.kompasiana.com/mirunachan/5a658064bde575784327ea02/impor-berassebagai-kebijakan-pangan-nasional

https://nasional.sindonews.com/read/1273611/18/kebijakan-instan-dan-instabilitas-hargapangan-1515964302

Rauf, A. Wahid,Martina Sri Lestari. 2009. PemanfaatanKomoditasPanganLokalSebagai SumberPanganAlternatif Di Papua. BalaiPengkajianTeknologiPertanian Papua, Diakses DariHttp://Pustaka.Litbang.Deptan.Go.Id/Publikasi/P3282093.pdf PengembanganPanganLokalMenujuIndustrialisasiPanganLokal di PapuaJune 28, 2013 In "Uncategorised" PotensiUbiHutansebagaiAlternatifIndustrialisasidan KetahananPanganLokalJune 28, 2013In "Uncategorised" RagamJenisPangan Lokal IndonesiaApril 24, 2013InPangandanTeknologi" Supriada H. 2005. Potensi, Kendala Dan PeluangPengembangan Agroindustri Berbasis PanganLokalUbikayu. PusatAnalisisSosialEkonomidanKebijakanPertanian.

SupriyatidanSuryani. 2006. Peranan, Peluang, danKendalaPengembangan Agroindustri di Indonesia. PusatAnalisisSosialEkonomidanKebijakanPertanian.

http://bisnis.liputan6.com/read/545055/beras-analog-panganan-alternatif-penggantiberas-padi-dan-terigu

http://www.tempo.co/read/news/2013/03/26/090469444/Antisipasi-Krisis-

Pangan-Beras-Analog-Disiapkan

https://ekonomi.kompas.com/read/2017/01/19/163000126/serikat.petani.indonesia.kebija kan.pangan.masih.sebatas.produksi

https://www.matamatapolitik.com/opini-indonesia-butuh-kebijakan-pangan-yang-lebihbaik/

https://www.kompasiana.com/mirunachan/5a658064bde575784327ea02/impor-berassebagai-kebijakan-pangan-nasional

https://nasional.sindonews.com/read/1273611/18/kebijakan-instan-dan-instabilitas-hargapangan-1515964302 